\title{
MEETING BETWEEN SPECIES \\ NONHUMAN CREATURES FROM FOLKLORE AS CHARACTERS \\ OF FANTASY LITERATURE
}

MERJA LEPPÄLAHTI

Many folklore creatures live new lives in fantasy literature. In this article, I will discuss two Finnish fantasy books, Else Lassila's Hyväntuulenlaakso and Johanna Sinisalo's Ennen päivänlaskua ei voi. Both books are set in modern Finland, where there really exists a race of supernatural creatures similar to the supernatural races that exist in Finnish folklore. I intend to ascertain the links between folklore creatures and those present in these fantasy books. Does the presence of folklore contribute something special to fantasy literature? Keywords: folklore and fantasy, third life offolklore, Finnish folklore, Finnish fantasy literature.
Številna bitja iz folklore živijo svoje novo življenje v fantazijski književnosti. V̌̌lanku sta obravnavani finski fantazijski deli, Hyväntuulenlaakso (Dolina dobrega Meseca) Else Lassila in Ennen päivänlaskua ei voi (Ne pred sončnim zahodom) Johanne Sinisalo. Obe sta postavljeni v sodobno Finsko, kjer naj bi resnično obstajala vrsta nadnaravnih bitij, prav tako je vrsta takšnih bitij poznana $v$ finski folklori. Avtorico zanimajo skupne značilnosti teh bitij $v$ folklori in književnosti. Ali folklora dodaja fantazijski zgodbi kaj posebej značilnega?

Ključne besede: foklora in fantazija, tretje življenje folklore, finska golklora, finska fantazijska književnost.

There are very many different definitions for fantasy, but in this context it is enough to say that fantasy literature includes something "fantastic", something that does not exist in real life. Maria Nikolajeva $(1988,113)$ has defined the characteristic feature for fantasy books as the presence of some fantasy motive, e.g. a magic object or a fantastics creature. She calls these fantasy motives fantasemes.

The reproduction of existing authentic things is typical of the postmodern era (e.g. Allen 2000, 181-183). In fantasy, it is very common to borrow things from here and there, but in fantasy literature this borrowing does not entail simple reproduction. J. R. R. Tolkien (1997) has called the author who creates the fantasy world "a subcreator". However, this subcreator employs a number of various sources: elder fantasy, other literature, folk stories ...

Intertextuality is also a very important part of all fantasy. A fantasy text is usually a mix of very many things. Folk tradition is an important source of inspiration for fantasy literature. We have many examples of the use of folk tradition in this manner: Celtic fairies, East-Asian dragons, Nordic dwarfs, East-European vampires ... we can find all them on the pages of fantasy books. These creatures that inhabit these folktales are most often the fantasemes of fantasy books; their presence makes the stories fantastic. 


\section{LIVES OF FOLKLORE}

Lauri Honko (1990, 93-121) has written about folklore as a process. This process of folklore provides the formula for the "life story" of folklore. In his model, Honko has divided the life of folklore into 22 stages, some which can be consecutive, some also partly simultaneous. The first twelve are the stages of living folklore, which Honko has named the first life of folklore. In this first life of folklore one finds the following stages: folklore living naturally without any specific recognition; the initial internal identification/recognition of folklore; the external recognition of folklore; definition of folklore, etc. The eighth stage is collecting folklore and the nineth is conserving it in the archive (Honko 1990: 102-113).

The second life of folklore begins when folklore is taken from archives. There has been until then a break in the use of folklore, but in its second life, folklore is re-used, for example, in folk festivals. This second life can be related with emancipation, cultural politics, commercial use, and so on (Honko 1990: 113-119). This kind of second life can also occur when folk legends are used in making new stories. In Finland, for example, Eija Timonen has used folklore from archives for making books, TV-series, and CD-ROM material for children. She has described this process in her dissertation (Timonen 2004). These two lives of folklore emphasize the value of folklore as folklore. I am suggesting that the third life of folklore begins when this material is not valuable only as folklore, but primarily because of its interesting content (Leppälahti 2005). It seems clear to me that folklore creatures live their new lives in fantasy literature.

\section{SUPERNATURAL FOLK IN FINNISH BELIEF LEGENDS}

In Finnish folk stories, there are many types of supernatural beings. One classification divides supernatural beings into two groups: the first includes dead, ghost and spirit beings, and the other the so-called natural beings. Natural beings can furthermore be divided in solitary beings and social beings. A solitary being in Finland is typically an elf ( haltia) that takes care of a certain place: a house, a mill, a lake, a torrent, or a forest. Almost every place has its own elf, but there is only one elf in a place. On the contrary, trolls and underground folk are social beings. They are very much like humans; they have families and they live the way that humans used to live (Haavio 1942: 10-11).

Stories about trolls (peikko) have been told mostly in southern and western Finland. Finnish trolls are thought to live in forests; usually their homes are inside rocks and mountains. Near the place where trolls live, people can sometimes hear music, laughing and voices of many kinds as well as noises of everyday work. These trolls can be friendly: in one story, there is s a herder in the forest with his cows. Suddenly, he smells the aroma of newly baked bread in the middle of the forest. He asks "please, give 
me some, too". Soon, he finds warm bread lying on a stone near him. In some stories, trolls can come to neighboring human houses to ask to borrow tools that to which they have given their own (funny) names. Yet trolls can also steal children and change babies. They also can lure people into troll caverns from which there is little chance of escape. In conclusion, the trolls of these folktales can be either friendly or hostile.

Underground folk (maahiset) are thought to live mostly in northern Finland, especially in Lapland. Underground folk get their name because they presumably live underground in their own villages. They keep herd animals: often reindeers in the north, but also cows. Their herds are very good: big, fat and beautiful, and sometimes the cattle of underground folk are told to be white. In certain circumstances, a human can be lucky enough to get some of these fine animals by doing certain magic things. Underground folk can also be friendly to humans; sometimes a human man can even marry an underground girl. But underground folk can also be dangerous: they can steal children, change babies and lure people to the underworld for ever.

In Finnish fairy tales, supernatural beings can seem to be dangerous, but actually they are either helping a human hero, or, if nonhumans really are hostile, they usually are quite easy to beat - at least on the third attempt with some supernatural aid (Apo 1986: 16-17, 283). Finnish belief legends have a different point of view. These stories teach us that one must be alert at all times when dealing with nonhuman beings such as trolls and underground folk. In fairy tales, human beings may interact safely with the supernatural, meanwhile in belief legends, the supernatural is not under human's control (Stattin 1992: 44-45). Even if they are sometimes friendly, they are always potentially dangerous because as supernatural beings, as "others", they can do supernatural things. Fantasy literature follows very often this belief legend thinking: the meeting between human and nonhuman always includes the possibility of danger.

\section{A CASE: TWO FANTASY BOOKS WITH FOLKLORE CREATURES}

In this article, I focus on two Finnish fantasy books. These two books are quite different: one is for adults and the other is for children. One is very famous, the other one is known only in Finland. But both of these books are fantasy books dealing with creatures of folk tradition. I chose these books because they are very different. Yet together they represent examples of a larger genre: one could easily find additional similar books using folklore creatures.

Else Lassila's Hyväntuulenlaakso (The Valley of Good Mood) is a book for children that was published in 1995. It has not been translated into other languages, so it is available only in Finnish. Johanna Sinisalo's Ennen päivänlaskua ei voi (Not before sundown) is an adult book. This book was published in the year 2000; it won the Finlandia prize (the most important literature prize in Finland) in 2000 as well as other addi- 
tional prizes. This work has been translated into many languages, including English, Russian, French, Spanish, German, Czech, Polish, Swedish and Japanese.

The main character in Johanna Sinisalo's book Ennen päivänlaskua ei voi (in future EPV) is Mikael (male human). Mikael is a young photographer who finds a baby troll near his home and takes it home. In Else Lassila's Hyväntuulenlaakso (in future HTL), the main character is Kitja, a girl of underground folk. She crawls up from the underground valley through a small cave and meets a young human boy, Janne, who takes her into his home.

Both books are written in Finnish and are set in present day Finland. Sinisalo's book takes place in Tampere, which is a real town in southern Finland. The scene of Lassila's book is in northern Finland, Lapland, but the name of the place is not mentioned. In both books, the main themes are the secrets of the other, the supernatural world and the danger of knowing about it. Other important themes include the quest for knowledge and travel to another world.

\section{KNOWLEDGE}

In both of these books, a human man or boy meets a supernatural being, though at first he does not realize it. In the book EPV, trolls are thought to be rare animals, so Mikael thinks the troll is like a pet. Only in the end of the book does one realize that trolls are not only animals but an intelligent species. In the other book, HTL, Kitja looks like a normal human girl. Little by little, Janne begins to think that there is something special about her, and finally he understands that she isn't human at all.

Knowing and seeking knowledge is salient in the book EPV. Mikael has never seen a troll before, and he doesn't know anything about trolls. He seeks information from the internet and from books. He finds out that trolls have been living in the forests of Finland since ancient times. In spite of this, people don't see them often because they are very rare and because they hide themselves very well. Even scientists don't know very much about trolls.

For Mikael, it is important to gain additional knowledge because he has to find out more about how to take care of a baby troll, what it eats and so on. He reads many kinds of texts, including folklore studies and even Kalevala poems to learn more about trolls. In the book EPV, there are plenty of documents in which trolls are mentioned - many of these documents are real or could be real, but the "facts" about trolls are mostly additions by the author.

Mikael finds out many things about trolls, specifically the mistakes in the public knowledge about them. Because Mikael has a baby troll in his apartment, he becomes a kind of specialist whose knowledge about trolls is at least as good as that of scientists. He doesn't realize the most important thing until he meets the adult trolls: that they are not animals and they are clearly intelligent. 
In the book HTL, the search for knowledge is not so systematic, it is important for Janne to notice that Kitja isn't an ordinary girl but instead from another world. Janne has heard old stories about underground folk but these stories are like fairy tales for him: people know them but nobody really believes them. Janne doesn't seek explanations or more information, he just notices that Kitja is different. He also trusts Kitja and keeps her secret. Another aspect of the search for knowledge is represented in Kitja's yearning to see humans; it is what makes her leave her home in spite of the warnings on the part of her family and friends.

\section{SECRET AND DANGER}

In both books, the existence of the other world is a secret to humans. In the book HTL, people perhaps know stories about underground folk, but they consider these stories to be only old wives' tales, not serious knowledge. In the book EPV, the supernatural is explained very scientifically with many "documents." The troll is an animal with a scientific name, and Mikael even sees a stuffed troll in a natural history museum. This is a modern view of the troll: it is an animal, not a supernatural being.

In the EPV book, the troll is a secret. Mikael cannot tell anyone he has a baby troll in his home because trolls are rare wild animals that people are not allowed to keep at home as pets. Mikael is very fond of his little troll and wants to keep it no matter what. But the troll is a beast, and it grows quickly. Once, when Mikael is not at home, one of his friends comes to visit him. He happens to have Mikael's keys and he goes in. The troll attacks and kills the man. When Michel comes home, he sees the dead body and decides to escape with the troll.

The HTL book is told from the supernatural point of view. Kitja can't tell anyone about her home valley because the underground folk don't want humans to know about them. Old stories of valley people speak of the fact that the connection between valley people and humans would be dangerous to underground folk. The reason for this is that underground folk assimilate at once to anything new. Long ago they had one small connection to humans, and because of this connection the valley people forgot their own mother tongue and began to use human language. Because of their tendency to assimilate, they have to be very careful, and this is why they would not allow Kitja to meet humans. When Kitja meets humans, she also meets with ill humour and impoliteness. These are things that are completely unknown to valley people. Valley people are very kind and friendly to each other: everyone is happy in the valley. It is very dangerous for them if they come into contact with such negative human emotions. 


\section{ANOTHER WORLD}

In both books. a nonhuman being comes to the human world, meets humans and returns home. From the human point of view, the place where they come from is unknown, and nonhuman people don't want human people to know anything about them. The little troll - Mikael calls him Pessi - cannot speak, so it cannot disclose anything. Kitja knows that the valley must remain a secret to humans, so she keeps quiet, too.

J. R. R. Tolkien (1997) called the place of fantasy in a story a secondary world, and the world of the reader a primary world. Maria Nikolajeva has developed this further. In Nikolajeva's model, the reader's world does not exist; instead, both worlds are inside the book. The "usual" world in the books is the primary world and supernatural characters belong to the secondary world. In open secondary world stories, the main character travels at least once between worlds (Nikolajeva 1988: 36-37).

In these books, both supernatural and human characters are travelling between the two worlds. Kitja, a nonhuman, comes to the human world and returns to her own. Janne goes to Kitja's world after her when he is looking for her. Baby troll Pessi comes from the unknown forest and returns with Mikael when Mikael tries to find a safe place for Pessi after he killed a man.

In folklore stories and belief legends, it is very often hard to get away once someone happens to get into trolls' or underground folk's abode. We can see these cases as well. When Janne falls to the Valley of Good Mood, the underground people are very friendly and polite to him, but they also explain to him that the law compels them to keep Janne there forever. The valley of Good Mood is supernatural in itself. The valley protects its habitants. When Kitja returns home, she becomes invisible and unable to speak, so she cannot disseminate damaging things to others. Janne helps Kitja and the other people of the valley, and later the people of the valley decide to make an exception so that Janne may return to the human world after all. Janne and his valley friends can even maintain contact and meet every now and then.

When Mikael goes to the troll forest, he meets some adult trolls. They are bigger than human men and have guns in their hands. At least then he learns that trolls are not animals but an intelligent race. Perhaps this forest could be found on the map, but as the home of trolls, it is totally unknown to humans, and one can think of it as another world. The relationship between Mikael and the little troll also changes over time. At first, Mikael took care of the cute troll who was like a pet for him. In the forest, when Mikael and the young troll enter the world of trolls, they become more equal, like friends. When a group of big trolls take Mikael and Pessi with them into the forest, they enter hand in hand - and the story ends. We don't know what happens after that. 


\section{FOLKLORE AND FANTASY}

In both of these books, the interesting "other race" has been taken from folklore. As in folklore, the existence and presence of the supernatural is a mystery, a puzzling secret. A human has to seek knowledge to deal with this supernatural. In both books, a human can visit another world, the world of the supernatural. However, this knowledge and dealings with the supernatural are dangerous, too. Interactions between humans and supernatural races aren't without problems for both sides.

Fantasy stories are, after all, stories about us humans. When Else Lassila's Kitja wonders about human behaviour, the reader can study humans from the "outside", from the viewpoint of "other". Johanna Sinisalo deals also with this "other" by making her main character homosexual. As fantasy literature often does, these stories about human and nonhuman interactions make the reader look at normal things from new points of view and in a new light. Johanna Sinisalo herself has emphasized that with her book she intended to spur discussion concerning the relationship between human and nature (Sinisalo 2004, 25-29). In both books, meetings between human and nonhuman can also be seen as meetings between culture and nature. These nonhuman beings are folklore creatures that live in nature, outside of human towns and villages. They seem to live in perfect harmony with nature, unlike humans, who destroy nature with pollution and by building constructions and motorways. This makes us think about the role of nature in modern life. And what if in forests, outside of human culture, there really lived an intelligent species, not human?

Folklore creatures can be fantasemes, those characters that transform a story a fantasy. In both books, creatures from folklore are the only supernatural features of the stories. Otherwise, the stories are quite realistic: the scenes take place in a seemingly real Finnish neighbourhood, neither the human characters nor the events are very fantastic. Only a baby troll and the underground folk are departures from the real world, and through them the reader is informed of whole new worlds.

So, what is the role of folklore here? At first, folklore is that which is somewhat familiar; it is easy to use and easy to understand. Most readers have some kind of image of folklore creatures in her or his mind. In second place, folklore creatures often operate as symbols: the relationship with nature, a genuine style of life, perhaps even that which is a bit old fashioned but good. With folklore creatures, the author evokes such themes without emphasizing them verbally.

In my opinion, we can see here the third life of folklore. In this case, it is no longer important that folklore be authentic; for readers it is not even relevant that a certain phenonena be recognized as folklore at all. But folklore is familiar, interesting and "fantastic". That's all and that's enough. 


\section{REFERENCES}

Allen, Graham

2000 Intertextuality. London and New York: Routledge.

Apo, Satu

1986 Ihmesadun rakenne: juonien tyypit, pääjaksot ja henkilöasetelmat satakuntalaisessa kansansatuaineistossa. Helsinki: Finnish Literature Society. (In English: The Narrative World of Finnish Fairy Tales: Structure, Agency and Evaluation in Southwest Finnish Folktales. Helsinki: Finnish Academy of Sciences, 1995.)

Haavio, Martti

1942 Suomalaiset kodinhaltiat [Finnish elves]. Helsinki: WSOY.

Honko, Lauri

1990 Folkloreprosessi [The process of folklore]. Sananjalka 32: 93-121.

Lassila, Else

1995 Hyväntuulenlaakso. Helsinki: WSOY.

Leppälahti, Merja

2005 The Use of Scandinavian Legends in Fantasy Literature Today. Conference paper in Celtic-Nordic-Baltic Folklore Symposium on Folk Legends held in Reykjavik, Iceland 15.-18.6. 2005.

Nikolajeva, Maria

1988 The Magic Code: The Use of Magical Patterns in Fantasy for Children. Stockholm: Almqvist \& Wiksell International.

Sinisalo, Johanna

2000 Ennen päivänlaskua ei voi. Helsinki: Tammi.

2004 Fantasia lajityyppinä ja kirjailijan työvälineenä [Fantasy as a genre and the tool of the author.] In: Kristian Blomberg, Irma Hirsjärvi and Urpo Kovala (eds.), Fantasian monet maailmat. Helsinki: BTJ Kirjastopalvelu, 11-31.

Stattin, Jochum

1992 Näcken. Spelman eller gränsvakt? [Näcken (water elf), a musician or guardian of border?] Stockholm: Carlssons.

Timonen, Eija

2004 Perinne käsikirjoittajan työkaluna [Folklore as the tool of the scriptwriter]. Rovaniemi: University of Lapland.

Tolkien, J. R. R.

1997 [1947]On Fairy-Stories. In: Tolkien, Christopher (ed.), The Monsters and Critics. London: Harper Collins Publisher, 109-161.

\section{SREČANJA VRST \\ NEČLOVEŠKA BITJA IZ FOLKLORE KOT LIKI FANTAZIJSKE KNJIŽEVNOSTI}

Za fantazijo imamo več različnih definicij, vendar naj zadošča, da fantazijska književnost vključuje nekaj "fantastičnega", karv resničnem življenju ne obstaja. Fantazijski književnosti je ljudsko izročilo eden izmed dokaj pomembnih virov navdiha. Za to imamo številne 
zglede: keltske škrate, vzhodnoazijske zmaje, nordijske palčke, vzhodnoevropske vampirje idr. najdemo na straneh fantazijskih knjig. Fantastično besedilo je navadno mešanica številnih stvari in medbesedilnost je zelo pomemben del te književnosti.

Lauri Honko (1990: 93-121) je pisal o folklori kot procesu, pri čemer ima folklora dve življenji. Vprvem resnično živi vizvirnem okolju, drugo življenje je vzeto iz arhiva za nove rabe. Folklorna bitja imajo torej v fantazijski književnosti nova življenja. Tretje življenje folklore se začne, ko to gradivo ni cenjeno le kot folklora, temveč predvsem zaradi zanimive vsebine.

Tu sta obravnavani fantazijski knjigi Else Lassila Hyväntuulenlaakso (Dolina dobrega Meseca) in Ennenpäivänlaskuaeivoi (Ne pred sončnim zahodom) Johanne Sinisalo. Dogajanje obeh je postavljeno v sodobno Finsko, kjer dejansko živi vrsta nadnaravnih bitij, vendar ljudje zanje ne vedo. Glavne teme so skrivnost drugega, nadnaravni svet in nevarnost, da vemo zanj. Pomembna sta tudi iskanje znanja in prehod v drugi svet.

Zanimiva "druga vrsta " je vzeta iz folklore. Kakor v folklori sta obstoj in navzočnost nadnaravnega uganka, zapletena skrivnost. Človek mora poiskati znanje, da se znajde z nadnaravnim. V obeh knjigah ljudje lahko obiščejo drug svet, svet nadnaravnega. Vendar sta znanje in ukvarjanje z nadnaravnim tudi nevarna. Folklorna bitja se lahko povezujejo $z$ naravo, dobrimi starimi časi in dobrim načinom življenja. Na drugi strani pa so fantazijske zgodbe predvsem zgodbe o ljudeh, o nas. $Z$ branjem fantazijskih zgodb je mogoče premišljati o ljudeh »od zunaj«, iz očišča "drugega».

Merja Leppälahti, Folkloristics, University of Turku, Henrikinkatu 3, 20014 University of Turku, Finland, meleppa@utu.fi 
